\title{
DETERMINING HEIGHT OF BENCHES IN OPEN MINING OF STEEPLY-DIPPING DEPOSITS WITH CONSIDERATION OF ORE LOSSES AND DILUTION
}

\author{
Fomin Sergey Igorevich, Rodionov Alexandr Olegovich, \\ Ryzhkov Sergey Konstantinovich \\ Saint-Petersburg Mining University
}

Russian Federation, 199106, Saint Petersburg, Vasilievski Ostrov, 21 line, 2, Russia

\begin{abstract}
At present stage of the development of the mineral resource complex, a trend is seen to deterioration of geological and engineering conditions of mining ore deposits, which entails increase of losses and dilution of mineral, causing increase of the cost price of mineral production and processing. With consideration of the specified limiting conditions, the maximal net present value of deposit mining will be achieved with minimal economic loss resulted from mineral losses and dilution.

For the conditions of steeply-sloping ore pits, analysis was conducted of the impact of the bench height on the value of mineral losses and dilution, and necessary calculations were made to identify the degree of influence of the pit bench height and the height of the triangle of inmixed waster rocks on the values of losses and dilution by three possible modes of preparing a new horizon (in mining from the hanging wall to the bottom wall, in preparation across the ore body).

According to the results of the research, conclusions were made that the economic loss related to the losses and dilution, increase in direct proportion to the increase of bench heights; the mode of horizon preparation significantly influences the value of losses and dilution and the economic losses related to them; the value of losses and dilution increases with increase of bench height, and the current stripping ratio reduces. For this reason, for determining the optimal bench height, joint consideration of the losses and dilution with the current stripping ratio, is required. The conducted technical and economic calculations result in recommending the bench height in ore zone, equal to $5 \mathrm{~m}$. with maintaining the rock bench height of 20 meters
\end{abstract}

Keywords: deposit, mineral dilution, economic loss, bench height, pit, stripping ratio

Cite this Article: Fomin Sergey Igorevich, Rodionov Alexandr Olegovich and Ryzhkov Sergey Konstantinovich, Determining Height of Benches in Open Mining of Steeply-Dipping Deposits with Consideration of Ore Losses and Dilution, International Journal of Advanced Research in Engineering and Technology, 10(3), 2019, pp. 225 233.

http://iaeme.com/Home/issue/IJARET?Volume=10\&Issue $=3$ 


\section{INTRODUCTION}

Losses and dilution of mineral result in reduction of the output of product and the volumes produced and processed ore, which, in turn, results in the increase of the current stripping ratio and the share of depreciation allocations [1]. Ultimately, these factors contribute to the cost price increase of mineral production and processing and decrease the profit.

Considering the abovementioned limiting conditions, the maximal value of the net present value of a deposit mining (holding all other conditions equal), will be obtained at the minimal economic loss from loss and dilution.

Knowing the values of $\Delta P$ and $\Delta V$, it is possible to identify the economic loss caused by mineral losses and dilution. When mineral losses and dilution do not affect extraction of useful components and the quality of concentrates, the economic loss (L) is

$$
\begin{aligned}
& \mathrm{L}=\left(l_{k} \cdot \varepsilon_{T} \cdot \operatorname{Pr}_{u}-a_{w}+s-d-a_{M}-d_{M}-r_{0}\right) \Delta P \cdot \gamma_{0}+ \\
& +\Delta V \cdot \gamma_{\mathrm{w}}\left(a_{w}+d+a_{M}+d_{M}+r_{0}-s-1_{\mathrm{u}} \cdot \varepsilon_{T} \cdot \operatorname{Pr}_{u}\right),
\end{aligned}
$$

where $\Delta P$ is the volume of ore lost at the contact, $\mathrm{m}^{3} ; \Delta V$ is the volume of diluent mass,

$\mathrm{m}^{3} ; \gamma_{0}$ is the volume mass of geological ore, $\mathrm{t} / \mathrm{m}^{3} ; l_{\mathrm{k}}$ is the content of useful component of ore body contact; $l_{u}$ is the useful component in the diluent rock; $\varepsilon_{\mathrm{T}}$ is extraction of useful component into concentrate from commodity ore; $\operatorname{Pr}_{u}$ is the price of the useful component in lost ore, roubles/t; $\quad a_{w}$ is the cost price of ore excavation without consideration of post-stripping reclamation, roubles/t; $s$ are costs for lost ore excavation and removal from the pit, roubles/t; $d$ is the cost price of ore processing at the dressing plant, roubles/t; $a_{M}$ are specific depreciation allocations per ton of ore balance reserves; $\mathrm{d}_{\mathrm{M}}$ are specific depreciation allocations per ton of processed ore when the dressing plant operates with full load; $r_{0}$ are unit costs for prospecting of 1 ton of ore balance reserves; $\gamma_{\mathrm{w}}$ is the volume weight of the diluent rock, $\mathrm{t} / \mathrm{m}^{3}$ [2].

Calculated values are adopted by the data of counterpart deposits and pits.

Function $\mathrm{L}=f(\Delta P, \Delta V)$ has minimum region, and for this reason, it is possible to find such a ratio between $\Delta P$ and $\Delta V$, at which a company will make a maximum possible profit under the following conditions [3].

Equation (1) implies that the minimum of $L$ value can be achieved in two ways:

1) Reduction of mineral losses $\Delta P$ and admixture of waste rocks $\Delta V$;

2) Identifying the optimal ratio of $\Delta P$ and $\Delta V$.

\section{METHODS}

Analysis of the schemes shown in figure 1 and equation (1) indicates that the first condition is fulfilled via reduction of bench height $h$, and the second condition is fulfilled via determining the height of the triangle of admixed waste rocks $a$, in which, the optimal ratio is ensured between the volumes of lost ore and admixed waste rock (at fixed bench height).

To determine the minimum economic loss, we find derivative $\frac{d \mathrm{~L}}{d a}$ of equation 1 , equate it to zero and calculate $a_{\mathrm{opt}}$ which is the optimal value of the triangle of admixed waste rocks $a$.

In $a_{\text {opt }}$, the optimal ratio is achieved between the value of losses and dilution, ensuring minimum economic loss, if the ore body contacts are regular, 
Fomin Sergey Igorevich, Rodionov Alexandr Olegovich and Ryzhkov Sergey Konstantinovich

$$
a_{0}=\frac{h \cdot \gamma_{0} \cdot\left(l_{k} \cdot \varepsilon_{T} \cdot \operatorname{Pr}_{u}-a+\mathrm{s}-d-a_{M}-d_{M}-r_{0}\right)}{\gamma_{0}\left(l_{k} \cdot \varepsilon_{T} \cdot \operatorname{Pr}_{u}-a+\mathrm{s}-d-a_{M}-d_{M}-r_{0}\right)+\gamma_{\mathrm{w}}\left(a+d+a_{M}+d_{M}+r_{0}-\mathrm{s}-l_{\Pi} \cdot \varepsilon_{T} \cdot \operatorname{Pr}_{u}\right)},
$$

For ore pit conditions, necessary calculations were performed in accordance with the abovementioned methods with the purpose of studying the impacts of the bench height on the loss values and dilution. The calculation results are given in figures 1 and 2 .

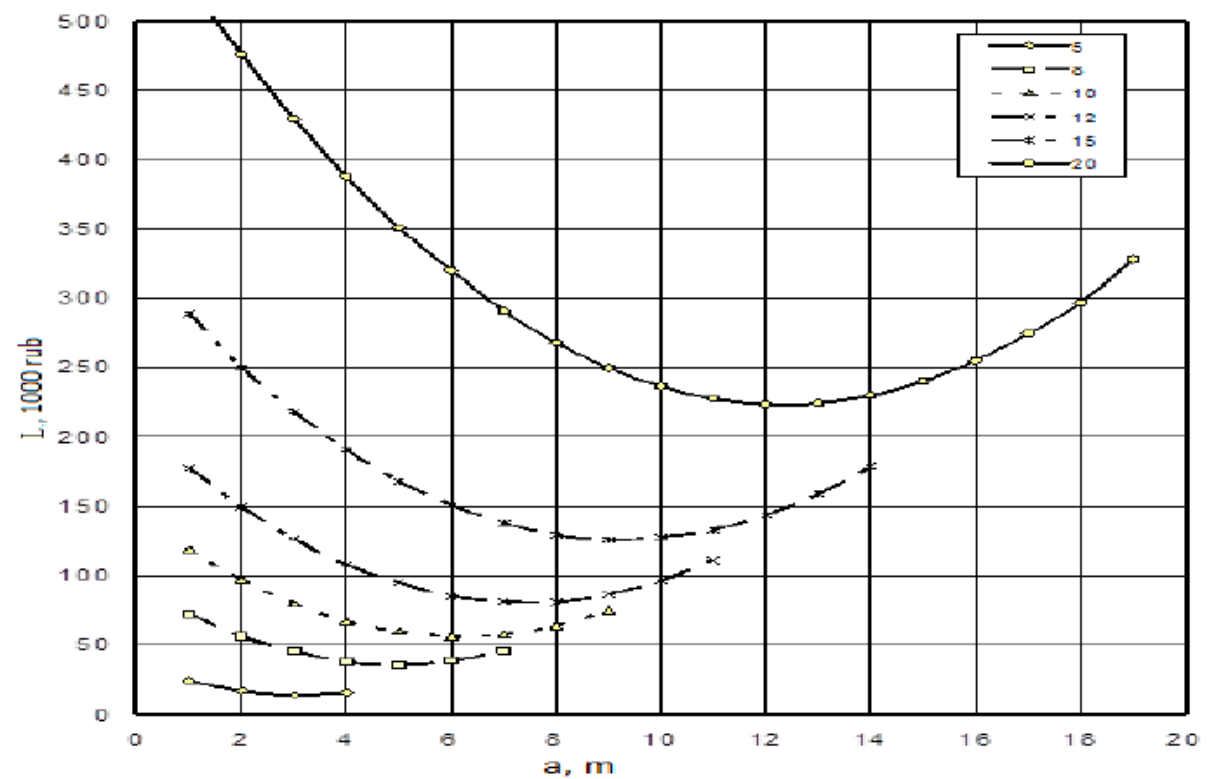

Figure 1 Graph $\mathrm{L}=f(\mathrm{a})$ for different values of $\mathrm{h}$ - bench height, with operation from hanging wall to bottom wall

When considering mineral losses and dilution, it is expedient to consider the values of bench heights, most common in pits [4], of 5, 8, 10, 12, 15, $20 \mathrm{~m}$.

Value $a$ which reflects the ratio between the volumes of lost ore and admixed rock, can be assumed as divisible by $1 \mathrm{~m}$, which ensures enough accuracy of the results.

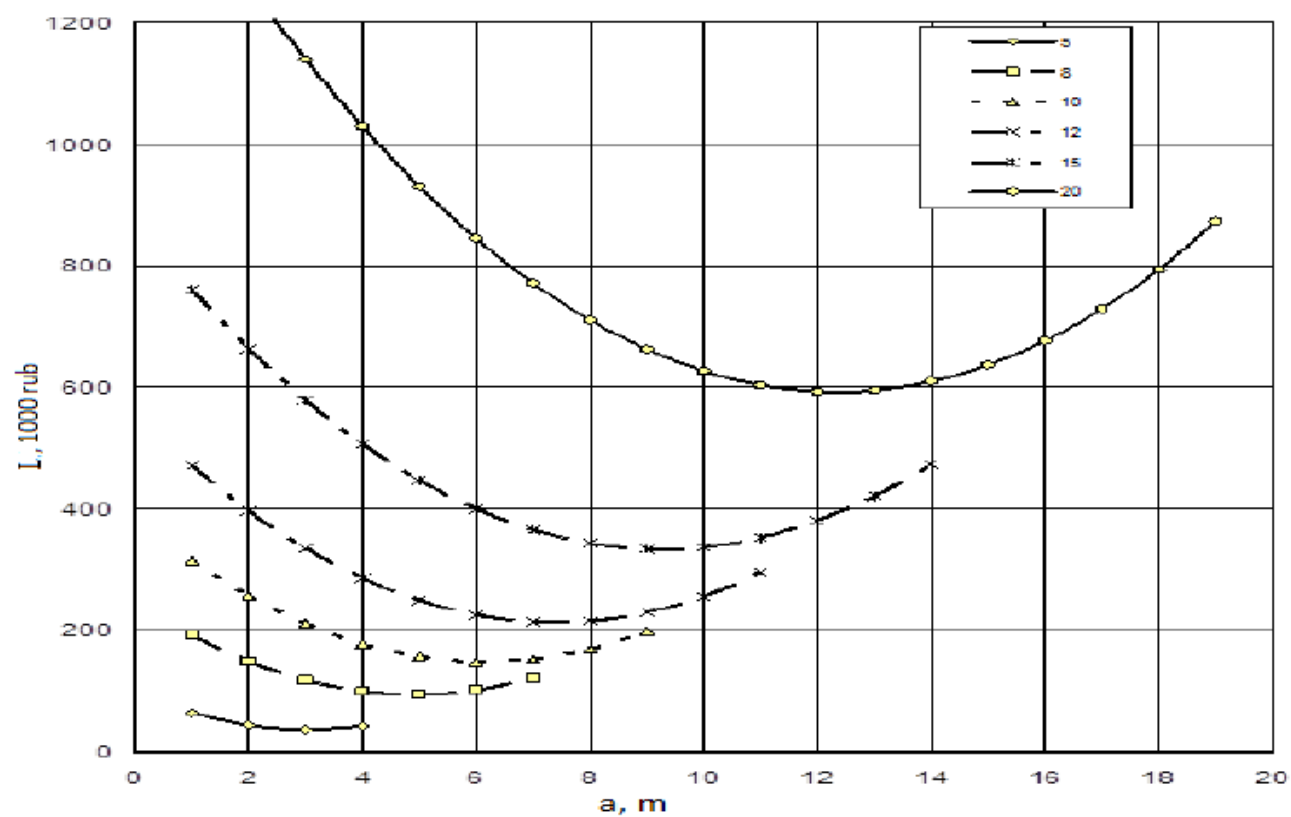

Figure 2 Graph $\mathrm{L}=f(\mathrm{a})$ for different values of $\mathrm{h}$ - bench height, with operation from bottom wall to hanging wall 
Determining Height of Benches in Open Mining of Steeply-Dipping Deposits with Consideration of Ore Losses and Dilution

\section{RESULTS}

Analysis of graphs $\mathrm{L}=f(\mathrm{a})$, shown in fig. 1 and 2, enables to make the following conclusions:

- With increase of the bench height, volumes of lost ore and admixed waste rock increase for each bench [5];

- Value $a_{\text {opt }}$ of minimum economic loss from losses and dilution, increasing by the absolute value with increase of the bench height, remains constant in relation to certain value $h$ (irrespectively of the mining font advancing in relation to ore body occurrence).

The resulting graph for this type of studies is graph $\mathrm{L}=f(h)$ - changes of the value of the economic loss related to losses and dilutions, for the pit in general (Figure 3).

The number of benches in the pit is different at their different height. The height of the triangle of admixed waste rocks $a$ is assumed in calculations as equal to $a_{\text {opt. }}$.

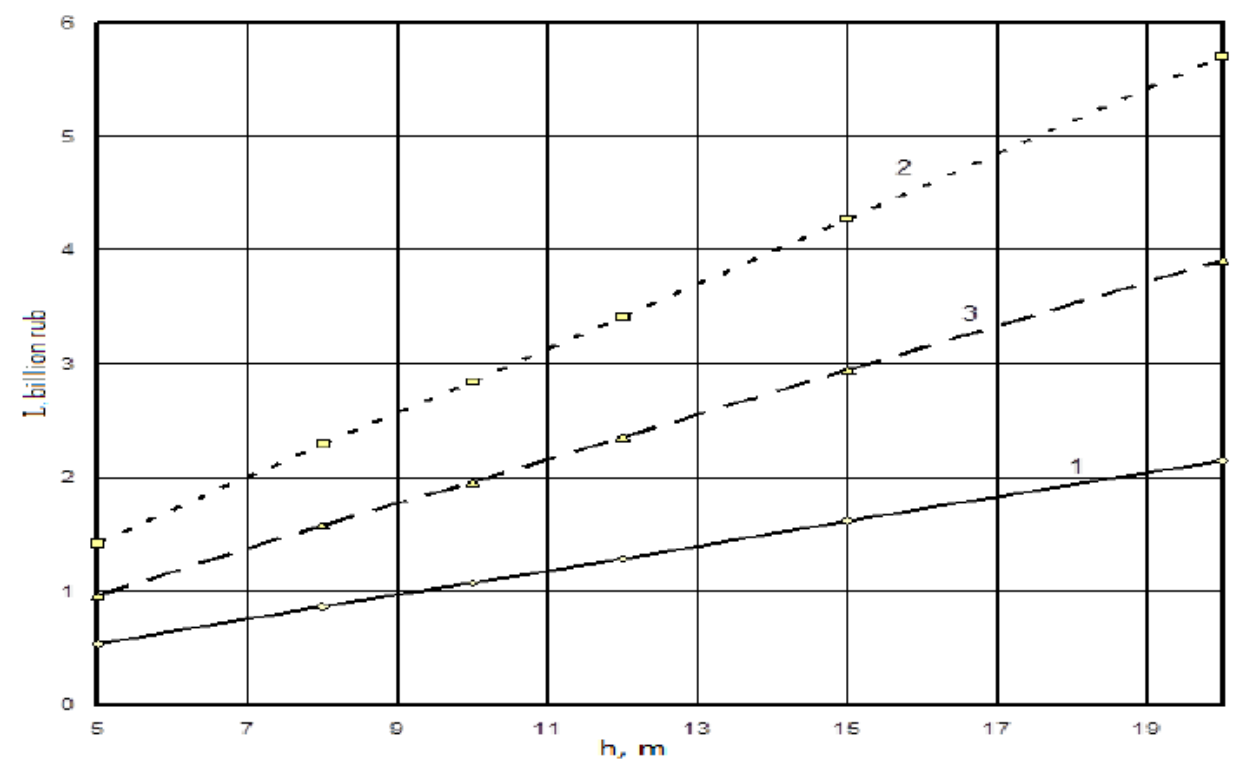

Figure 3 Graph $\mathrm{L}=f(\mathrm{~h})$ Changes of the economic loss value related to losses and dilution, for the pit in general:

- In operation from hanging wall to bottom wall.

- In operation from bottom wall to hanging wall.

- In preparation across the ore body.

Table 1 shows value $\mathrm{a}_{0}$ - of optimal height of triangle of waste rocks admixture at different bench value $h$.

Table 1 Value an of optimal height of triangle of waste rocks admixture at different bench value $h$.

\begin{tabular}{|c|c|}
\hline $\mathbf{h}, \mathbf{m}$ & $\mathbf{a}_{\mathbf{0}}$ \\
\hline 5 & 3,1 \\
\hline 8 & 4,9 \\
\hline 10 & 6,2 \\
\hline 12 & 7,4 \\
\hline 15 & 9,3 \\
\hline 20 & 12,3 \\
\hline
\end{tabular}


All the calculations are conducted by three possible modes of horizon preparation [6]. According to the results of the studies, the following conclusions can be made:

- Economic losses related to losses and dilution, increase directly proportional to increase of bench heights;

- Horizon preparation mode significantly impacts the value of losses and dilution and the economic losses related to them;

- Both for an individual horizon and for the pit in general, with increase in bench heights, the value of losses and dilution increase.

With increase of the bench heights, in mining of steeply-dipping deposits, the current stripping ratio increases, and deposit mining becomes more economical [7].

At the same time, as it was substantiated above, with increase of the height of ore benches, economic losses caused by increasing losses and dilution [8], increase. These two contradictory factors in ore zone need to be taken into consideration.

\section{DISCUSSION}

Methodologically, this study can be performed as follows. In cross-sections, positions of mining works are indicated, corresponding to the marks of the pit bottom in each calendar year of deposit mining, with different values of $h$ and angle of slope of the pit working flank in the ore zone, but with the same values of $h$ in rock zone.

Then, the areas of extracted waste rock in each annual reduction, are measured and the current volumes of waste rock are identified in mining a deposit with different values of ore benches' height.

Then, discounted costs for removal waste rocks for the pit with various values $h$ in ore zone are calculated, and then they are compared [9].

Slope angles of pit working flanks [1].

$$
\varphi=\operatorname{arctg} \frac{\mathrm{h}}{\mathrm{B}+\mathrm{h} \cdot \operatorname{ctg} \alpha},
$$

where $\mathrm{B}$ is the width of the working areas, $\mathrm{m}$.

\section{Width of pit working areas [1].}

$$
\mathrm{B}=B_{\text {res }}+\Delta B,
$$

where $\mathrm{B}_{\text {resis }}$ the width of the reserve lane of the reserves on the horizon ready for extraction, $\mathrm{m}$;

$\Delta \mathrm{B}$ is the part of the working area, minimally necessary only for mining the underlying horizon, $\mathrm{m}$.

The value of discounted costs for removal of waste rocks from the pit, and the costs of future years, are given to the first year of operation [10], [11].

$$
C=\frac{V \cdot b}{(1+E)^{t}},
$$

where $\mathrm{V}$ are the volumes of stripped rocks removed annually in deposit mining by pit, $\mathrm{m}^{3}$; $b$ are the costs for waste rocks extraction and removal from the pit, roubles $/ \mathrm{m}^{3} ; E$ is the discount rate; $t$ is the discounting time period, years. 
Determining Height of Benches in Open Mining of Steeply-Dipping Deposits with Consideration of Ore Losses and Dilution

According to the results of the studies, the optimal height of ore benches was identified (with height of rock benches of $20 \mathrm{~m}$.), corresponding to the minimum costs of stripping works. The studies conducted for Ozerny pit, resulted in the following conclusions:

- Costs of extraction and removal of waste rocks are inversely proportional to ore bench height;

- Economic losses from losses and dilution are directly proportional to height of ore benches.

Obviously, for identifying $h_{\mathrm{opt}}$ by two main factors - costs for stripping works and economic losses from losses and dilution, it is necessary to summarize the graphs $\mathrm{C}=f\left(h_{\mathrm{opt}}\right)$ and $\mathrm{L}=$ $f\left(h_{\text {opt }}\right)[12]$, figure 4.

Minimum of function $\mathrm{C}+\mathrm{L}=f\left(h_{\mathrm{opt}}\right)$ will correspond to the optimal value of ore benches' height.

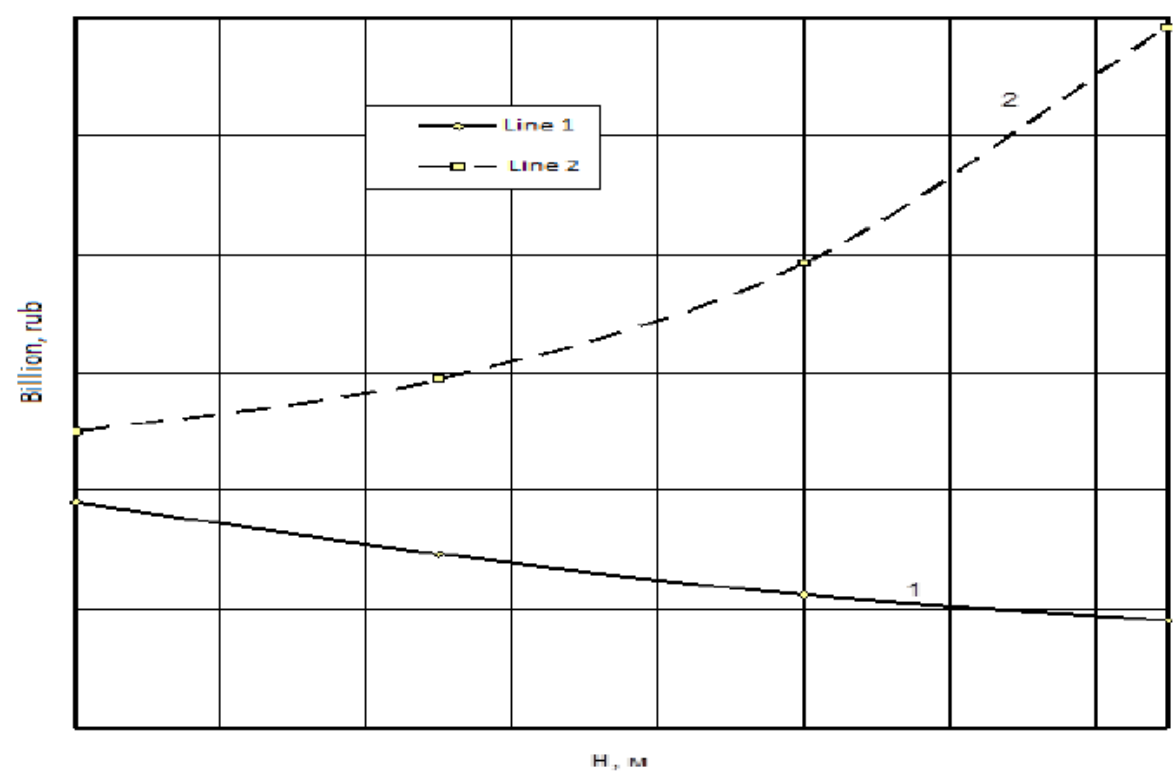

Figure 4 Graph $\mathrm{C}=f(h)$ for Ozerny pit

1 - graph of changing stripping works costs discounted in time. 2 - summary curve $\mathrm{C}+\mathrm{L}$ $=f(h)$.

Graphs (figure 4, curve 2) show that the minimum of function falls on the bench height in the ore zone $h_{\mathrm{opt}}=5 \mathrm{~m}$. In exiting the ore zone, 5 -meter benches need to be aggregated into 20meter benches. In this case, the loss coefficient will be $\eta=0.86 \%$, and the dilution ratio $я-\rho$ $=2.24 \%$.

With known value $a_{\text {опт }}$, corresponding to the minimum economic loss from losses and dilution in any contact, it is possible to identify the places of blast holes location in the contact places of ore and rock [13], which will ensure rock mass detachment along the assigned optimal line $\mathrm{AB}$ (Figure 5). 


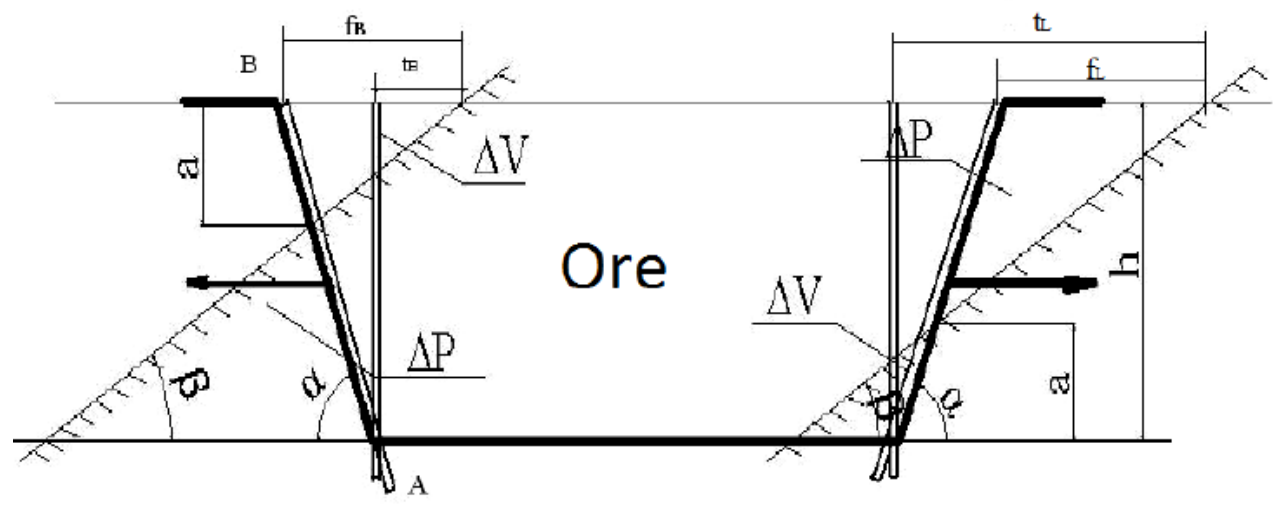

Figure 5 Scheme to the calculation of the place of blast hole location in the place of the contacts of ore and rock, ensuring rock mass detachment along the assigned optimal line $\mathrm{AB}$ [14].

Distance AB of inclined borehole (at bench slope angle) from the ore body contact (f) and the distance of the vertical borehole from the ore body contact $(\mathrm{t})$, with operation from the middle to ore body contacts with dipping angle of ore body $\beta<\alpha$ - slope angle of working bench [15]

a). For hanging wall

$$
\begin{aligned}
& f_{B}=a_{O}\left(\operatorname{ctg} \alpha+\operatorname{ctg} \beta_{B}\right), \mathrm{m} \\
& t_{B}=\left(a_{O}-h\right) \operatorname{ctg} \alpha+a_{o} \operatorname{ctg} \beta_{B}, \mathrm{~m}
\end{aligned}
$$

б). For bottom wall

$$
\begin{aligned}
& f_{\mathrm{L}}=\left(h-a_{O}\right)\left(\operatorname{ctg} \beta_{\mathrm{L}}-\operatorname{ctg} \alpha\right), \mathrm{m} \\
& t_{\mathrm{L}}=\left(h-a_{O}\right) \operatorname{ctg} \beta_{\mathrm{L}}+a_{o} \operatorname{ctg} \alpha, \mathrm{m}
\end{aligned}
$$

\section{CONCLUSION}

The following source data were used in the calculations:

Ore bench height $-\mathrm{h}=5 \mathrm{~m}$; bench slope angle $-\alpha=70^{\circ}$; optimal height of triangle of admixed stripped rocks - $\mathrm{a}_{0}=3.1 \mathrm{~m}$; weighted averages dipping angles of ore bodies (hanging wall $)-\beta_{\mathrm{B}}=39.3^{\circ}$, (bottom wall) $-\beta_{\mathrm{L}}=40.5^{\circ}$.

By formulas 4-8, calculation was performed of values $f_{B}, f_{L}, t_{B}, t_{L}$ :

$$
\mathrm{f}_{\mathrm{B}}=5.0 \mathrm{~m} ; \quad \mathrm{f}_{\mathrm{L}}=2.0 \mathrm{~m} ; \quad \mathrm{t}_{\mathrm{B}}=3.1 \mathrm{~m} ; \quad \mathrm{t}_{\mathrm{L}}=3.8 \mathrm{~m}
$$

Values $f$ and $t$ are calculated for weighted averages values of dipping angles of ore bodies [16]. However, some ore bodies have fairly low dipping angle - much lower than the natural slope angle of exploded rock mass, which complicates excavator loading.

Exploded ore will be placed on the bench slope and will be inaccessible to an excavator shovel. In this case, for feeding ore to the excavator, bulldozers can be used, or bench height can be reduced to some extent.

In the pit, steep-slope dipping ore bodies occur, and in exploding charges in inclined boreholes of big diameter, detachment line of rock mass can have not the assigned angles, but a lower angle. In this case, the boreholes' diameter should be reduced [17]. 
Determining Height of Benches in Open Mining of Steeply-Dipping Deposits with Consideration of Ore Losses and Dilution

The performed studies enabled to make the following conclusions and recommendations:

1. Weighted averages dipping angles of ore bodies:

- From the hanging wall side $-39.3^{\circ}$;

- From the bottom wall side $-40.5^{\circ}$.

2. On the basis of the weighted averages of the dipping angles of ore bodies, identified in this work, the rational level of losses and dilution factor will be as follows: $\eta=0.86 \%, \rho=2,24 \%$.

3. Joint consideration of losses and dilution with the current stripping ratio and technical and economic calculations enable to recommend in the ore zone, the bench height of 5 meters with maintaining the rock benches height of 20 meters.

\section{REFERENCES}

[1] Trubetskoi K.N. Designing pits: Textbook for universities. In 2 volumes. $-2^{\text {nd }}$ edition, with revisions and additions. Moscow: Publishing House of Academy of Mining Sciences, 2001. - V. I. - 519 pages.

[2] Arsentiev A. I. Pit productivity: Monography. / A. I. Arsentiev. Saint Petersburg Mining University named After G.V. Plekhanov (technical university). - Saint Petersburg: Publishing House of SPGGI (TU), 2002, 85 pages.

[3] Hill J.H. Geological and economical estimate of mining projects // London, 1993. - 85 p.

[4] Kovalski, E. R., Karpov, G. N., Leisle, A. V. Investigation of underground entries deformation mechanisms within zones of high stresses. International Journal of Civil Engineering and Technology, 9(6), 2018, 534-543.

[5] Leisle, A. V., Kovalski, E. R. Complex extraction of methane and coal from thick coal seams. Research Journal of Pharmaceutical, Biological and Chemical Sciences, 7(3), 2016, 16601666.

[6] Hustrulid W. Open Pit Mine: Planning \& Design. / W. Hustrulid, M. Kuchta. - Rotterdam; Brookfield, VT: A.A. Balkema, 1998. -735 p.

[7] Schröder D. L., Large surface miners - applications and cost calculations // Krupp Fördertechnik GmbH, Essen, Germany, February, 1999, - 98 p.

[8] B. Burke, Improving Mining efficiency with through Seam Blasting.: 2014.-C.31

[9] Karpov, G. N., Kovalski, E. R. (2017). Mode of forming dismantle chamber in mining gentlysloping coal-beds. Journal of Industrial Pollution Control, 33(1), 834-839

[10] Fomin S.I., Pasynkov D.V., Ivanov V.V. Analysis of effects of mineral resources market factors on productivity of pits. Collection of scientific works "Contemporary Issues of Mining Science". St. Petersburg Mining University (Technical University). Notes of Mining Institute, Saint Petersburg. Volume 172. 2007. Pages 121 -125.

[11] Fomin S.I., Justification of technological solutions in organizing mining of ore pits// Notes of Mining Institute. 2016. Volume 221. Pages 644-650.

[12] Ganitski V.I. Mining management. Glossary. Moscow: Gornaya Kniga publishing house. 2013. 472 pages.

[13] Roslavtseva Yu.G., Fedorko V.P. Mining journal. Izvestia VUZov, Justification of choice of rational mode of mining works, Yekaterinburg, 2010. Pages 20-26.

[14] Fomin S.I., Vedrova D.A. The Mining technology of a thick overburden layer covering a group of flat dipping coal seams // Mine planning and equipment selection. Vol.1, Dresden, Germany, Springer, 2013, pp. 75-81. 
Fomin Sergey Igorevich, Rodionov Alexandr Olegovich and Ryzhkov Sergey Konstantinovich

[15] Rakishev B.R. Stripping pit fields and systems of open development: Textbook. Almaty, 2012. 320 pages.

[16] Koryakin A.I., Selyukov A.V. Determining main technological parameters of pit in designing. Kemerovo: Kuzbassvuzizdat, 2012. 124 pages.

[17] Rakishev B.R. Designing pits: Training manual. Almaty: KazNTU, 2013. 298 pages.

[18] Deepalakshmi. R and Jothi Venkateswaran C, A Survey on Mining Methods for Protein Sequence Analysis: An Aerial View, International Journal of Computer Engineering and Technology (IJCET), Volume 3, Issue 2, July- September (2012), pp. 28-34.

[19] Prakash Kumar and Rajak A.K, Advanced Functional Maintenance Management for Mining Excavator, International Journal of Mechanical Engineering and Technology (IJMET), Volume 5, Issue 4, April (2014), pp. 199-205.

[20] Rahul Shajan and Gladston Raj S, Association Rule Mining Based Analysis on Horoscope Data - A Perspective Study, International Journal of Computer Engineering \& Technology, 8(2), 2017, pp.76-81. 